\title{
Gambaran Kebutuhan Keluarga Pasien di Ruang Instalasi Gawat Darurat
}

\author{
I Putu Krisna Widya Nugraha1, Dody Setyawan² \\ 1,2 Universitas Diponegoro
}

\begin{tabular}{ll}
\hline \multicolumn{1}{c}{ Article Info } & \multicolumn{1}{c}{ Abstract } \\
\hline Article History: & $\begin{array}{l}\text { The patient's condition and the environment of the Emergency Installation } \\
\text { Accepted May 18th } 2019\end{array}$ \\
$\begin{array}{l}\text { Key words: } \\
\text { family. This causes the emergence of psychological problems in the } \\
\text { patient's family, such as anxiety, stress, and depression, these problems can } \\
\text { Room; Patient Family }\end{array}$ & $\begin{array}{l}\text { affect the role of the family as a supporting system of patients in the } \\
\text { process of handling actions while in the ER. These problems can be } \\
\text { minimized by fulfilling family needs while in the ER to accompany the } \\
\text { patient. The purpose of this study is to find out the description of the } \\
\text { patient's family needs in the emergency room. This research is a } \\
\text { descriptive quantitative study with a survey approach, with the research } \\
\text { instrument in the form of a CCFNI-ED questionnaire. Respondents } \\
\text { numbered 96 patient families obtained through convenience sampling } \\
\text { techniques. The results of this study indicate that family needs which } \\
\text { according to the family are important to fulfill are communication needs } \\
\text { followed by understandable needs, support needs, comfort needs and } \\
\text { needs close to the patient. Communication needs are considered the most } \\
\text { important needs needed by the patient's family while in the emergency } \\
\text { room. This research is expected to be a source of reference for the nursing } \\
\text { profession in meeting family needs while in the emergency room, so it is } \\
\text { expected to increase the family's role in healing patients. }\end{array}$ \\
\hline
\end{tabular}

\section{PENDAHULUAN}

Instalasi gawat darurat merupakan salah satu bagian di rumah sakit yang memberikan pelayanan kesehatan kepada masyarakat secara paripurna. Instalasi gawat darurat (IGD) merupakan gerbang utama masuknya penderita gawat darurat dirumah sakit. Selain itu IGD merupakan lingkungan perawatan yang unik dimana tim kesehatan, pasien dan keluarga dihadapkan dengan kejadian yang tidak terduga setiap waktunya terhadap kondisi pasien(Hsiao et al., 2016) IGD menjadi bagian paling terdepan dan sangat berperan dirumah sakit, dimana pelayanan yang diberikan mempunyai aspek khusus karena berkaitan dengan penanganan kondisi mengancam nyawa atau kecacatan seseorang.Dalam meningkatkan kualitas pelayanan dan menjadikan kepercayaan terhadap pelanggan, IGD harus mampu menunjukan performa pelayanan yang baik dengan dapat memenuhi segala bentuk kebutuhan pasien dan keluarga.

Pasien yang datang di IGD kondisinya berbeda - beda, terdapat pasien dengan tingkat kegawatan yang ringan bahkan sampai gawat darurat. Perawat

Corresponding author:

I Putu Krisna Widya Nugraha putukrisna.undip@gmail.com Jurnal Kepemimpinan dan Manajemen Keperawatan, Vol 2 No 1, May 2019 DOI: http://dx.doi.org/10.32584/jkmk.v2i1.198 
bertanggung jawab melakukan triase untuk memilih kondisi pasien mana yang harus segera didahulukan. Tindakan tersebut dilakukan karena prinsip penanganan di IGD adalah mencegah mortalitas atau morbiditas. Kondisi tersebut membuat perawat dan tim medis lebih fokus dalam menangani pasien. Penelitian yang pernah dilakukan Jamil, tahun 2015 di IGD Rumah Sakit Wava Husada Kepanjen Malang dengan pendekatan kualitatif tentang pengalaman keluarga dalam mendampingi pasien di IGD menunjukan bahwa penanganan ke pasien lebih utama dibandingkan komunikasi dengan keluarga, perawat enggan memberikan penjelasan kepada keluarga dan keluarga masih merasa terabaikan. Kepadatan pasien yang datang ke IGD, kondisi pasien yang kompleks serta pelayanan perawat IGD yang dituntut untuk multitasking dinilai sebagai faktor penghambat perawat untuk memenuhi kebutuhan keluarga pasien(Malley, Brown, \& Krug, 2017)

Berdasarkan data Jenderal Bina Pelayanan Medik Depkes tahun 2007 jumlah kunjungan pasien ke IGD di Indonesia adalah 4.402 .205 pasien $(13 \%)$ dari total seluruh kunjungan di rumah sakit umum. Banyaknya pasien yang datang untuk ditangani berdampak pada terbatasnya pemenuhan kebutuhan keluarga pasien(Tulay \& Zeynep, 2018) Pelayanan di IGD tidak hanya berfokus pada pemenuhan kebutuhan pasien yang gawat darurat saja, akan tetapi juga kebutuhan keluarga yang datang mengantarkan pasien tersebut (Marti, Andarini, \& Lestari, 2015) Keluarga pasien merupakan bagian terpenting untuk diperhatikan dalam pelayanan di IGD. Keluarga pasien yang datang ke IGD biasanya memiliki tingkat stres dan kecemasan yang tinggi(Dicle \& Firat, 2016)

Penelitian Mega tahun 2017 menunjukan sebanyak 48,8\% keluarga pasien mengalami tingkat kecemasan yang berat khususnya pada mereka yang anggota keluarganya masuk di triase merah. Kematian pasien, perubahan peran, kebutuhan finansial dan lingkungan yang tidak familiar menjadi sebab terjadinya stres dan kecemasan keluarga. Penelitian yang dilakukan Lukmanulhakim et al, tahun 2016 di IGD Rumah sakit dr. Drajat Prawiranegara menggambarkan sebanyak $42,6 \%$ anggota keluarga mengalami kecemasan sedang. Keluarga pasien yang sedang menunggu di IGD merasa cemas, berharap ada perubahan terhadap keluarga yang sakit, dan merasa tidak berdaya(Yoon \& Sonneveld, 2010) Penyebab stress dan kecemasan keluarga adalah adanya beberapa kebutuhan keluarga yang belum maksimal terpenuhi(Dicle \& Firat, 2016) Menurut Redley, tahun 2003 kebutuhan keluarga tersebut adalah kebutuhan kedekatan dengan pasien, komunikasi, dukungan, kenyamanan dan dimengerti. Penelitian Tulay dan Zeynep tahun 2018 tentang kebutuhan keluarga di IGD Rumah Sakit Universitas Ataturk didapatkan hasil bahwa kebutuhan komunikasi merupakan kebutuhan yang paling penting menurut keluarga yang mendampingi pasien di IGD. Hasil penelitian di salah satu rumah sakit Gauteng juga menjelaskan bahwa kebutuhan komunikasi merupakan kebutuhan yang paling dirasa belum terpenuhi oleh keluarga(Meghan \& Langley, 2015)

Sakit dan sehatnya anggota keluarga akan berdampak pada keluarga yang lainnya(Brysiewicz \& Emmamally, 2017) Hal ini dapat mempengaruhi keluarga dalam mengambil keputusan (decision making) untuk menentukan tindakan medis yang akan dilakukan pada pasien. Masalah tersebut juga bisa mempengaruhi peran keluarga sebagai supporting system dalam proses penanganan tindakan selama di IGD(Redley \& Beanland, 2004)

Hasil studi pendahuluan yang dilakukan peneliti didapatkan data Jumlah kedatangan pasien ke IGD RSUD Dr.Moewardi Surakarta dalam tiga bulan terakhir (November 2017Januari 2018) adalah 7.035 pasien dengan rata-rata 2.345 pasien. Menurut Supratman, tahun 2009 rata-rata rasio perawat-pasien 
di RSUD Dr.Moewardi Surakarta adalah 1:9 yang berarti 1 orang perawat bertanggung jawab terhadap 9 orang pasien. Banyaknya kunjungan pasien tersebut di IGD berisiko penanganan hanya berfokus pada kegawatdaruratan pasien saja. Berdasarkan uraian fenomena di atas, peneliti ingin mengetahui Gambaran Kebutuhan Keluarga Pasien di Ruang Instalasi Gawat Darurat RSUD Dr.Moewardi Surakarta.

\section{METODE}

Penelitian ini merupakan penelitian kuantitatif non-eksperimental dengan desain deskriptif survei. Responden berjumlah 96 keluarga pasien yang berada di IGD RSUD Dr.Moewardi Surakarta.Pengambilan sampel menggunakan Convenience sampling. Instrumen menggunakan kuesioner Critical Care Inventory Needs-Emergency Department (CCFNI-ED) yang telah dimodifikasi oleh Bernice Redley. Kuesioner memiliki 40 item yang terdiri dari 5 item kebutuhan dekat dengan pasien, 11 item kebutuhan komunikasi, 9 item kebutuhan dukungan, 6 item kebutuhan kenyamanan, 9 item kebutuhan dimengerti. Kuesioner menggunakan skala likert yang bersifat positif (favorable) dengan pilihan jawaban sangat penting, penting, cukup penting, dan tidak penting. Kuesioner telah dilakukan uji validitas oleh peneliti pada 30 responden di IGD RSUD Tugurejo Semarang dengan nilai $r$ hitung adalah $0,315-0,756 \geq \mathrm{r}$ tabel 0,3061 sehingga valid, kuesioner ini memiliki nilai rerata alpha cronbach 0,920 , sehingga CCFNI-ED sudah reliabel. Penelitian telah mendapatkan ethical clearance dengan nomor No.61/KEPK/VII/2018. Analisa data yang digunakan adalah analisa univariat.

\section{HASIL}

1. Karakteristik Responden

Tabel 1

Karakteristik Responden Keluarga Pasien IGD

\begin{tabular}{llcc}
\hline \multicolumn{1}{c}{ Indikator } & $\mathrm{f}$ & $\%$ \\
\hline 1. Jenis Kelamin & & \\
& a. Laki-laki & 60 & 62,5 \\
& b. Perempuan & 36 & 37,5 \\
\hline 2. & Tingkat Pendidikan & & \\
a. SD & 7 & 7,3 \\
b. SMP & 12 & 12,5 \\
c. SMA & 71 & 74 \\
d. PT & 6 & 6,3 \\
\hline
\end{tabular}

3. Hubungan dengan pasien

\begin{tabular}{lcc} 
a. Suami & 20 & 20 \\
b. Istri & 16 & 16,7 \\
c. Anak & 33 & 34,4 \\
d. Orang tua & 9 & 9,4 \\
e. Saudara Kandung & 18 & 18,8 \\
\hline
\end{tabular}

4. Usia (Rerata) 35,25

2. Rata-rata Kebutuhan Keluarga Pasien berdasarkan Sub Kebutuhan

Tabel 2

Rata-rata Kebutuhan Keluarga Pasien berdasarkan Sub Kebutuhan

\begin{tabular}{llcc}
\hline & \multicolumn{1}{c}{ Indikator } & Rerata & SD \\
\hline 1. & Kebutuhan Komunikasi & 31,2 & 4,86 \\
\hline 2. & Kebutuhan Dimengerti & 26,7 & 3,41 \\
\hline 3. & Kebutuhan Dukungan & 24,1 & 3,45 \\
\hline 4. & $\begin{array}{l}\text { Kebutuhan } \\
\text { Kenyamanan }\end{array}$ & 16,0 & 4,16 \\
\hline 5. & $\begin{array}{l}\text { Kebutuhan Dekat } \\
\text { dengan pasien }\end{array}$ & 15,1 & 2,16 \\
\hline
\end{tabular}

\section{DISKUSI}

Hasil penelitian ini menunjukan bahwa kebutuhan komunikasi merupakan kebutuhan yang menurut keluarga paling penting untuk didapatkan saat berada di lingkungan IGD, yaitu dengan nilai mean sebesar 31,2. Hasil tersebut sejalan dengan penelitian Hsiao di Taiwan tahun 2016 
bahwa keluarga pasien di IGD menggolongkan kebutuhan komunikasi terhadap keluarga yang paling penting dengan rata-rata 3,66 lebih tinggi daripada kebutuhan yang lain. Keluarga yang kurang informasi mengenai kondisi pasien dapat mempengaruhi proses pengambilan keputusan untuk menentukan langkah kolaboratif dengan perawat dalam menentukan tindakan. Tidak lengkapnya informasi yang diberikan oleh perawat kepada keluarga dapat menimbulkan faktor-faktor peningkat kecemasan pada keluarga pasien. Penelitian Tulay, tahun 2018 juga menjelaskan bahwa secara berurutan kebutuhan yang menurut keluarga penting yaitu kebutuhan komunikasi, kebutuhan dukungan, kebutuhan dimengerti dan kebutuhan kenyamanan.

Perawatan berorientasi keluarga pada keterampilan komunikasi tidak hanya membantu keluarga tetapi juga mengurangi depresi, kecemasan dan stress pada pasien(Ghazavi, Feshangchi, Alavi, \& Keshvari, 2016) Dalam mengatasi kecemasan keluarga selama berada di IGD perawat memiliki peran sebagai pemberi asuhan keperawataan, sebagai edukator dan sebagai advokat bagi keluarga pasien. Peran perawat tersebut bisa dilakukan saat perawat melakukan komunikasi kepada keluarga pasien. Hasil Penelitian Handayani dan Sofyanur, tahun 2018 di RSUD Dr. Zainal Abidin Banda Aceh menjelaskan peran perawat sebagai pemberi asuhan keperawatan dalam mengatasi kecemasan keluarga pada saat masuk instalasi gawat darurat berada pada kategori baik $(77,1 \%)$, Adapun peran perawat sebagai edukator dalam mengatasi kecemasan keluarga pada saat masuk instalasi gawat darurat berada pada kategori baik $(65,6 \%)$,dan peran perawat sebagai advokad dalam mengatasi kecemasan keluarga pada saat masuk instalasi gawat darurat berada pada kategori baik (76\%).

Kebutuhan komunikasi merupakan kebutuhan keluarga untuk mendapatkan informasi yang jelas mengenai kondisi pasien dan lingkungan IGD(Redley \& Beanland, 2004) Keluarga yang kurang informasi mengenai kondisi pasien dapat mempengaruhi proses pengambilan keputusan untuk menentukan langkah kolaboratif dengan perawat dalam menentukan tindakan. Pada penelitian ini, responden menganggap sangat penting pada pernyataan keluarga mendapatkan penjelasan dari perawat dengan istilah yang mudah dipahami. Pernyataan lain yang menurut keluarga sangat penting dibutuhkan yaitu dokter atau perawat memberitahu kondisi keluarga yang sakit (pasien) sebelum keluarga diminta menandatangani dokumen. Hal ini sejalan dengan penelitian Wagiu et al, tahun 2017 dengan pendekatan kualitatif yang menjelaskan bahwa penggunaan informed consent di IGD tetap dipakai walaupun kondisi gawat darurat yaitu dengan menyampaikannya secara lisan baru setelah selesai tindakan dimintakan tanda tangan. Akan tetapi, hasil penelitian ini menunjukan masih terdapat keluarga yang menganggap tidak penting pada pernyataan keluarga diperkenalkan oleh perawat dengan para staf IGD. Hal ini tidak sejalan dengan hasil peneltian Malliarou et al, tahun 2014 yang menjelaskan kebutuhan keluarga pasien di IGD adalah memastikan keluarga tahu nama perawat karena dengan mengetahui perawat penanggungjawab, keluarga merasa dapat menanyakan semua hal tentang pasien. Keluarga juga menganggap tidak penting pada pernyataan perawat tidak memberikan informasi detail yang menyedihkan kepada keluarga tentang penyakit pasien. Hal ini menjadi tidak penting karena menurut keluarga perawat seharusnya memberikan semua informasi mengenai perkembangan kondisi pasien kepada keluarga. Pernyataan lain yang menurut keluarga tidak penting yaitu keluarga diberi informasi terkait keahlian perawat yang merawat keluarga pasien. Keluarga beranggapan bahwa komunikasi sebenarnya penting, tetapi yang lebih dipentingkan adalah penanganan kepada pasien, beberapa keluarga pasien juga 
beranggapan bahwa komunikasi memperpanjang waktu tunggu pasien mendapat penanganan(Jamil, 2015)

Kebutuhan dimengerti merupakan kebutuhan yang diharapkan keluarga pasien untuk selalu mendapatkan pengertian terkait kondisi sulit yang sedang mereka hadapi. Penelitian yang dilakukan Meghan dan Langley, tahun 2015 tentang kebutuhan keluarga di unit gawat darurat menyatakan bahwa kebutuhan dimengerti merupakan kebutuhan yang sangat penting untuk dipenuhi. Hasil penelitian ini sebagian responden menganggap sangat penting pada pernyataan keluarga merasa bahwa perawat IGD peduli dengan keluarga mereka yang sakit. Hal tersebut didukung penelitan Dewi, tahun 2016 dengan pendekatan kualitatif pada perawat IGD RSUD Tarakan yang menjelaskan bentuk caring perawat diwujudkan dalam bentuk kemampuan perawat dalam mendengarkan keluh dan kesah pasien dan keluarga. Akan tetapi sebagian responden beranggapan tidak penting pada pernyataan keluarga diberi informasi oleh perawat mengenai aktivitas ibadah. Hal ini didukung oleh penelitian Dicle dan Firat, tahun 2016 yang menjelaskan bahwa keluarga lebih membutuhakan prioritas tindakan penanganan terhadap pasien dibandingkan keluarga mendapatkan informasi mengenai layanan ibadah selama berada di IGD, hal tersebut dibuktikan dengan nilai mean pernyataan keluarga mendapat informasi mengenai layanan keagamaan sebesar 2,68 lebih kecil dibandingkan dengan kebutuhan yang lain.

Kebutuhan dukungan merupakan kebutuhan yang berhubungan dengan keluarga merasa dapat mencurahkan perasaanya dan mendapat perhatian dari perawat, dokter dan staff di IGD. Hasil penelitian Tulay dan Zeynep, tahun 2018 menunjukan bahwa kebutuhan dukungan keluarga menempati peringkat nomor dua menurut nilai mean dibandingkan dengan empat kebutuhan keluarga lainnya. Hasil penelitian ini pada kebutuhan dukungan keluarga menganggap sangat penting pada pernyataan perawat menyambut keluarga saat tiba di rumah sakit. Hal ini didukung oleh penelitian Shital dan Dino, tahun 2015 bahwa menyambut keluarga pasien saat di triase dapat menenangkan keluarga dan memberikan peluang kepada keluarga untuk menceritakan riwayat pasien. Respon time perawat kepada pasien saat di triase dalam menemui pasien dan keluarga dapat menurunkan tingkat kecemasan keluarga (Mega, 2017) Pernyataan lain yang sangat penting menurut keluarga yaitu keluarga dijelaskan terkait apa yang harus dilakukan saat menunggu pasien. Hal ini sejalan dengan penelitian Handayani dan Sofyannur, tahun 2018 yang menjelaskan bahwa peran perawat sebagai edukator yaitu menjelaskan dan memberikan pengajaran kepada keluarga mengenai kewajiban keluarga yang harus dilakukan keluarga saat menunggu pasien. Akan tetapi masih ada responden yang menganggap tidak penting pada pernyataan keluarga dijelaskan mengenai respon emosional yang wajar. Hal ini didukung oleh penelitian Dicle dan Firat, tahun 2016 tentang kebutuhan keluarga yang menjelaskan nilai mean pada pernyataan keluarga dijelaskan mengenai respon emosional lebih kecil dibandingan pernyataan kebutuhan yang berhubungan dengan tindakan penanganan pada pasien.

Kebutuhan kenyamanan merupakan kebutuhan yang berhubungan dengan keluarga dapat merasakan kenyamanan dengan fasilitas yang ada di ruang tunggu. Kenyamanan yang dirasakan oleh keluarga meliputi kenyamanan fisik dan kenyamanan emosionalnya. Hasil penelitian Hebert, tahun 2014 menjelaskan terpenuhinya kebutuhan kenyamanan diharapkan dapat meringankan kecemasan yang dialami keluarga dan memberikan kesempatan keluarga untuk beristirahat. Pada penelitian ini pada kebutuhan kenyamanan keluarga menganggap sangat penting pada pernyataan keluarga diyakinkan perawat terkait aspek kenyamanan yang diberikan bagi keluarga yang sakit. Hal ini sejalan dengan penelitian Septiani, tahun 2016 
yang menjelaskan bahwa tedapat hubungan yang signifikan antara kepuasan keluarga pasien terhadap kenyamanan ruangan (dimensi tangible) di RSUD Kabupaten Sumedang $p$ value $=0,000$. Pernyataan lain yang menurut keluarga sangat penting yaitu keluarga difasilitasi terkait ruang tunggu. Hasil observasi peneliti, ruang tunggu keluarga IGD di RSUD Dr.Moewardi berada di luar tepatnya berada di samping IGD. Permenkes RI No.858 Tahun 2009 tentang standar IGD yang menjelaskan bahwa rumah sakit tipe A wajib memiliki ruang tunggu di IGD yang nyaman dan memadai. Dalam penelitian ini, masih terdapat responden yang menganggap tidak penting pada pernyataan keluarga diberikan informasi terkait fasilitas tempat makan dekat IGD. Menurut hasil penelitian Lukmanulhakin et al, tahun 2016 keluarga yang berada di lingkungan IGD cenderung lebih membutuhkan informasi detail yang berhubungan dengan perkembangan kondisi pasien dibandingkan dengan informasi yang lainnya.

Kebutuhan dekat dengan pasien (proximity) selama di IGD didefinisakan sebagai hubungan yang dekat antara keluarga dan anggota keluarganya yang sedang sakit (Redley et al, 2003). Penelitian Ose, tahun 2017 menjelaskan kehadiran keluarga didekat pasien diharapkan mampu memberikan dukungan emosional dan perasaan nyaman pada pasien. Pada penelitian ini Kebutuhan dekat dengan pasien yang sangat penting dibutuhkan oleh keluarga yaitu keluarga diberikan kesempatan oleh perawat untuk dapat melihat kondisi pasien sesegera mungkin. Hal ini didukung oleh penelitian Malley et al, tahun 2013 yang menjelaskan bahwa kehadiran keluarga didekat pasien selama diberikan tindakan oleh petugas medis dapat membuat pasien tenang dan membantu petugas dalam membuat suatu keputusan (decision making). Kebutuhan lainnya yang dianggap sangat penting bagi keluarga yaitu keluarga diberikan penjelasan oleh perawat tentang apa yang sedang terjadi pada pasien. Hal ini sejalan dengan penelitian Malliarou et al, tahun 2014 yang menyatakan bahwa mendapat penjelasan terkait kondisi pasien dan mengetahui prognosis sakit yang dialami merupakan kebutuhan utama keluarga yang mendampingi pasien di IGD. Akan tetapi, hasil penelitian ini menunjukan masih ada keluarga yang beranggapan tidak penting pada pernyataan perawat tidak memperbolehkan keluarga campur tangan selama perawatan pasien. Hal ini didukung oleh penelitian Dudley et al, tahun 2017 yang menyatakan keluarga hanya sebatas menemani, memberikan informasi mengenai pasien dan membantu petugas membuat keputusan selama di IGD.

\section{SIMPULAN}

Hasil penelitian ini menunjukan kebutuhan komunikasi merupakan kebutuhan yang dianggap paling penting oleh keluarga pasien IGD diikuti dengan kebutuhan dimengerti,kebutuhan dukungan, kebutuhan kenyamanan dan kebutuhan dekat dengan pasien. Peneliti menyarankan kepada perawat untuk lebih memperhatikan pemenuhan kebutuhan keluarga pasien.

\section{REFERENSI}

Brysiewicz, P., \& Emmamally, W. (2017). Focusing on families in the emergency department. International Emergency Nursing, 30, 1-2. https://doi.org/10.1016/j.ienj.2016.08.002

Dicle, A., \& Firat, M. Z. (2016). Psychometric properties of the critical care family needs inventory-emergency department. Applied Nursing Research, 33, 113-120. https://doi.org/10.1016/j.apnr.2016.11.001

Ghazavi, Z., Feshangchi, S., Alavi, M., \& Keshvari, M. (2016). Effect of a Family-Oriented Communication Skills Training Program on Depression, Anxiety, and Stress in Older Adults : A Randomized Clinical Trial. 5(1), 1-8. https://doi.org/10.17795/nmsjournal28550

Hsiao, P.-R., Redley, B., Hsiao, Y.-C., Lin, C.-C., Han, C.Y., \& Lin, H.-R. (2016). Family Needs of Critically Ill Patients in the Emergency Department. International Emergency Nursing. 
https://doi.org/10.1016/j.ienj.2016.05.002

Jamil, M. (2015). Studi Fenomenologi: Pengalaman Keluarga Pasien dalam Berkomunikasi dengan Perawat di Prioritas 2 (P2) Instalasi Gawat Darurat. Jurnal Kesehatan Hesti Wira Sakti, 3, 44-53.

Malley, P. J. O., Brown, K., \& Krug, S. E. (2017). Patient- and Family-Centered Care of Children in the Emergency Department. 122(2). https://doi.org/10.1542/peds.2008-1569

Marti, E., Andarini, S., \& Lestari, R. (2015). Studi Fenomenologi Penerapan Prinsip Patient Centered Care Pada Saat Proses Resusitasi di IGD RSUD Saiful Anwar Malang. The Indonesian Journal of Health Science, 6(1), 73-89.

Mega, P. G. (2017). Hubungan Respon Time Perawat Dengan Tingkat Kecemasan Keluarga Pasien di Triage Merah (Prioritas 2) Rumah Sakit Umum Daerah Dr.Moewardi. Stikes Kusuma Husada.

Meghan, B., \& Langley, G. (2015). The needs of families accompanying injured patients into the emergency department in a tertiary hospital in Gauteng. Curationis, 39(1), 1-7. https://doi.org/http://dx.doi.org/10.4102/cur ationis.v39i1.1567

Redley, B., \& Beanland, C. (2004). Revising the Critical Care Family Needs Inventory for the Emergency Department. Journal of Advanced Nursing, 45(1), 95-104. https://doi.org/10.1046/j.13652648.2003.02865.x

Tulay, Y., \& Zeynep, O. K. (2018). Needs of Critically Ill Patients' Relatives in Emergency Departments. Nursing and Midwifery Studies, 7, 33-38. https://doi.org/10.4103/nms.nms

Yoon, J., \& Sonneveld, M. (2010). Anxiety of patients in the waiting room of the emergency department. Proceedings of the Fourth International Conference on Tangible, Embedded, and Embodied Interaction - TEI '10, (February 2015), 279. https://doi.org/10.1145/1709886.1709946 